\title{
Epigenetic Re-Expression of Hemoglobin F Using Reversible LSD1 Inhibitors - Potential Therapies for Sickle Cell Disease
}

\author{
Steven Holshouser, ${ }^{1}$ Rebecca Cafiero, ${ }^{1}$ Mayra Robinson, ${ }^{1}$ Joy Kirkpatrick, ${ }^{1}$ Robert A. Casero, ${ }^{2}$ Jr.,
} Hyacinth I. Hyacinth ${ }^{3}$ and Patrick M. Woster. ${ }^{1 *}$

${ }^{1}$ Department of Drug Discovery and Biomedical Sciences, Medical University of South Carolina, 70 President St., Charleston, SC 29414, USA; ${ }^{2}$ Sidney Kimmel Comprehensive Cancer Center, Johns Hopkins School of Medicine, 1650 Orleans St. Room 551, Baltimore, MD 21287, USA; ${ }^{3}$ Department of Pediatrics, School of Medicine, Emory University, 2015 Uppergate Dr., Atlanta, GA 30322, USA.

KEYWORDS: Epigenetics; lysine-specific demethylase 1; hemoglobin F; sickle cell disease.

\section{Supporting Information}

\section{Synthesis (all compounds in this manuscript have been previously reported)}

All reagents and dry solvents were purchased from Aldrich Chemical Co. (Milwaukee, WI), Sigma Chemical Co. (St. Louis, MO), VWR (Radnor, PA) or Fisher Scientific (Chicago, IL) and were used without further purification except as noted below. Triethylamine was distilled from potassium hydroxide and stored in a nitrogen atmosphere. Dry methanol, ethyl acetate, tetrahydrofuran, dimethyl formamide and hexane were prepared using a Glass Contour Solvent Purification System (Pure Process Technology, LLC, Nashua, NH). Preparative scale chromatographic procedures were carried out using a CombiFlash Rf200 chromatography system (Teledyne-Isco, Lincoln, NE) fitted with silica gel 60 cartridges (230-440 mesh). Thin layer chromatography was conducted on Merck precoated silica gel 60 F-254. Ion exchange chromatography was conducted on Dowex1X8-200 anion exchange resin.

All ${ }^{1} \mathrm{H}$ - and ${ }^{13} \mathrm{C}-\mathrm{NMR}$ spectra were recorded on a Bruker Avance $600 \mathrm{MHz}$ spectrometer, and all chemical shifts are reported as $\delta$ values referenced to TMS or DSS. Splitting patterns are indicated as follows: s, singlet; d, doublet; t, triplet; m, multiplet; br, broad peak. In all cases, ${ }^{1} \mathrm{H}-\mathrm{NMR},{ }^{13} \mathrm{C}-\mathrm{NMR}$ and MS spectra were consistent with assigned structures. Mass spectra were recorded by LC/MS on a Waters autopurification liquid chromatography with a model 3100 mass spectrometer detector. Prior to biological testing procedures, all compounds were determined to be $>95 \%$ pure by UPLC chromatography $\left(95 \% \mathrm{H}_{2} \mathrm{O} / 5 \%\right.$ acetonitrile to $20 \% \mathrm{H}_{2} \mathrm{O} / 80 \%$ acetonitrile over 10 minutes) using a Waters Acquity $\mathrm{H}$-series ultrahigh-performance liquid chromatograph fitted with a $\mathrm{C} 18$ reversed-phase column (Acquity UPLC BEH C18 $1.7 \mathrm{M}, 2.1$ X $50 \mathrm{~mm}$ ). Compounds 4-11 were synthesized according to the general procedures described below.

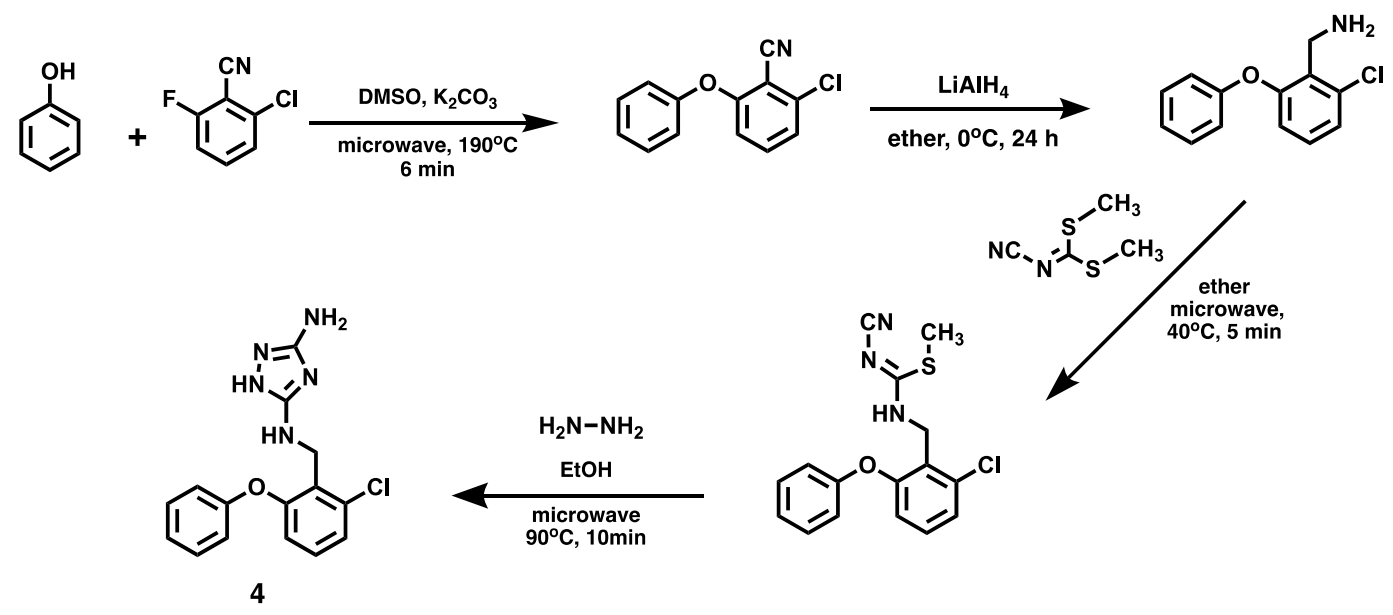

Scheme S1. Synthetic route to 3,5-diamino-1,2,4-triazole analogues 4-6. 


\section{Method A ${ }^{1}$}

General procedure for the synthesis of substituted 2-chloro-6-aryloxybenzonitriles

Synthesis of 2-chloro-6-phenyloxybenzonitrile. To a $20 \mathrm{~mL}$ microwave vial containing a magnetic stir bar was added $0.78 \mathrm{~g}(5.0 \mathrm{mmol})$ of 2-fluoro-6-chlorobenzonitrile, $(1.04 \mathrm{~g}, 7.5 \mathrm{mmol})$ of $\mathrm{K}_{2} \mathrm{CO}_{3}, 0.52 \mathrm{~g}(5.5 \mathrm{mmol})$ of phenol and $12.0 \mathrm{~mL}$ of anhydrous DMSO. The vial was then sealed and stirred to distribute the contents evenly. The mixture was then microwaved at $190^{\circ} \mathrm{C}$ for $6 \mathrm{~min}$ at high absorption to insure even heating. The reaction mixture was poured into a beaker containing $100 \mathrm{~mL}$ of crushed ice to precipitate the product. The aqueous layer was extracted with three 50 $\mathrm{mL}$ portions of diethyl ether, and the ether layer was washed with $25 \mathrm{~mL}$ of saturated $\mathrm{NaCl}$, dried over anhydrous $\mathrm{Na}_{2} \mathrm{SO}_{4}$, filtered, and the ether was removed in vacuo to yield $1.11 \mathrm{~g}$ of the desired diaryl ether (97\% yield). The crude product was pure enough to be used in the next reaction without further purification.

\section{General procedure for the synthesis of substituted 2-chloro-6-aryloxybenzylamines}

Synthesis of 2-chloro-6-phenyloxybenzylamine. A $1.11 \mathrm{~g}$ portion of 2-chloro-6-phenoxybenzonitrile (4.8 mmol) was dissolved in $50 \mathrm{~mL}$ of anhydrous diethyl ether, cooled to $0^{\circ} \mathrm{C}$ in an ice bath and stirred while bubbling dry argon into the reaction mixture for $10 \mathrm{~min}$. A $14.49 \mathrm{~mL}$ portion of $1.0 \mathrm{M} \mathrm{LiAlH}_{4}$ in THF $(14.49 \mathrm{mmol})$ was then added dropwise with stirring over $20 \mathrm{~min}$. The resulting reaction mixture was allowed to stir for $2 \mathrm{hrs}$ at $0^{\circ} \mathrm{C}$, and then warmed to room temperature and allowed to stir overnight. The mixture was cooled to $0^{\circ} \mathrm{C}$, and the reaction was quenched by the slow addition of $\mathrm{Na}_{2} \mathrm{SO}_{4} \bullet 10 \mathrm{H}_{2} \mathrm{O}$. When the evolution of gas subsided, the reaction was stirred for 30 min at room temperature, and the mixture was filtered through a Celite pad. The filtrate was concentrated to dryness to yield crude 2-chloro-6-benzoxybenzylamine. The crude product was pure enough to be used in the next reaction without further purification.

\section{General procedure for the synthesis of substituted $N^{3}$-(2-chloro-6-aryloxybenzyl)-1H-1,2,4-triazole-3,5-diamines}

Synthesis of $N^{3}$-(2-chloro-6-phenoxybenzyl)-1H-1,2,4-triazole-3,5-diamine, 4. A $0.935 \mathrm{~g}$ portion of 2-chloro-6phenoxybenzyl amine $(4.0 \mathrm{mmol})$ was dissolved in $12 \mathrm{~mL}$ of diethyl ether and added to a $20 \mathrm{~mL}$ microwave vial equipped with a magnetic stir bar. A $0.702 \mathrm{~g}$ portion of dimethyl cyanodithioiminocarbonate $(4.8 \mathrm{mmol})$ was added and the vial was sealed. The contents were microwaved at $45^{\circ} \mathrm{C}$ for $5 \mathrm{~min}$, cooled to room temperature, and the ether was removed in vacuo to yield the intermediate as a white to pale yellow solid. A $0.192 \mathrm{~g}$ portion of hydrazine hydrate $(6.0 \mathrm{mmol})$ in $12 \mathrm{~mL}$ of dry ethanol was then injected, the vial was stirred to break up the solid intermediate, and the resulting mixture was microwaved at $90^{\circ} \mathrm{C}$ for $10 \mathrm{~min}$ at high absorption. The ethanol was removed in vacuo, and the residue was purified by silica gel chromatography $\left(9 \% \mathrm{MeOH}\right.$ in $\left.\mathrm{CH}_{2} \mathrm{Cl}_{2}\right)$ to afford $1.07 \mathrm{~g}$ of pure $4(85 \%)$ as an offwhite, amorphous solid. ${ }^{1} \mathrm{H}-\mathrm{NMR}\left(400 \mathrm{MHz}, \mathrm{CD}_{3} \mathrm{OD} / \mathrm{TMS}\right) \delta 4.21(\mathrm{~s}, 2 \mathrm{H}), 6.77-6.80(\mathrm{dd}, 1 \mathrm{H}), 6.99-7.01(\mathrm{~d}, 2 \mathrm{H})$, 7.11-7.15 $(\mathrm{t}, 1 \mathrm{H}), 7.20-7.27(\mathrm{~m}, 2 \mathrm{H}), 7.33-7.38(\mathrm{t}, 2 \mathrm{H})$. UPLC retention time: $12.1 \mathrm{~min}$. MS calculated 315.09, found $316.33\left([\mathrm{M}+1]^{+}\right)$

\section{Method B ${ }^{2}$}

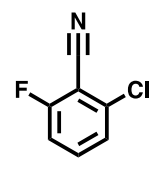

12

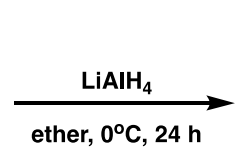

ether, $0^{\circ} \mathrm{C}, 24 \mathrm{~h}$

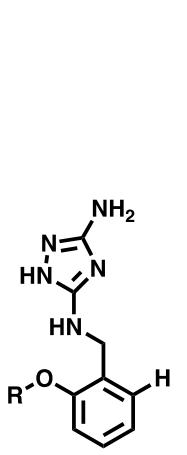

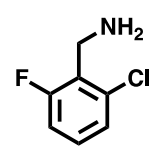

13

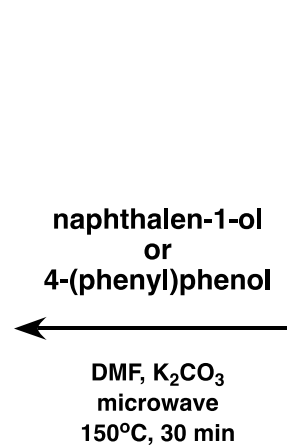

$150^{\circ} \mathrm{C}, 30 \mathrm{~min}$

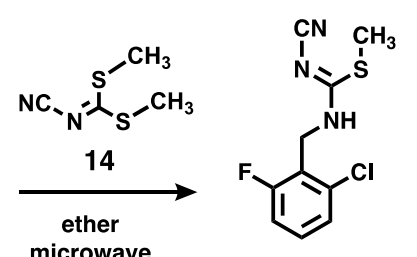

15
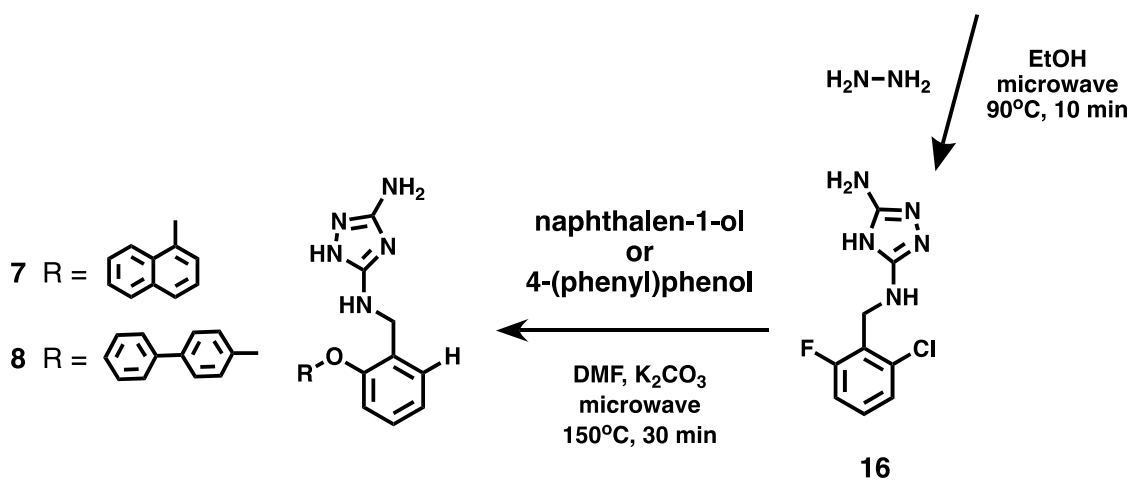

16

Scheme S2. Synthetic route to dechlorinated compounds $\mathbf{7}$ and $\mathbf{8}$. 
Synthesis of 2-chloro-6-fluorobenzylamine, 13. 2-chloro-6-fluorobenzonitrile 12 (1.0 g, $6.43 \mathrm{mmol})$ was dissolved in $50 \mathrm{~mL}$ of diethyl ether and stirred at $0^{\circ} \mathrm{C}$ while bubbling argon through the solution for 10 minutes, followed by the dropwise addition of $15 \mathrm{~mL}$ (3.0 equivalents) of $1.0 \mathrm{M} \mathrm{LiAlH}_{4}$ in THF over $20 \mathrm{~min}$. Following addition of the reducing agent, the reaction was stirred for 2 hours at $0^{\circ} \mathrm{C}$, warmed to room temperature and allowed to stir overnight. The reaction was cooled to $0^{\circ} \mathrm{C}$ and quenched by slow addition of $\mathrm{Na}_{2} \mathrm{SO}_{4} \bullet 10 \mathrm{H}_{2} \mathrm{O}$. When the evolution of gas was complete, the reaction was warmed to room temperature and allowed to stir for an additional 30 minutes, and then filtered through a Celite pad. The filtrate was then concentrated to dryness in vacuo. The crude material was purified on silica $(0-5 \% \mathrm{MeOH}$ in dichloromethane), to produce the desired 2-chloro-6-fluorobenzylamine $13(0.913 \mathrm{~g}, 89 \%$ yield). ${ }^{1} \mathrm{H}$ NMR (400 MHz, $\left.\mathrm{CDCl}_{3}\right) \delta 4.88(\mathrm{~s}, 2 \mathrm{H}), 7.09(\mathrm{~m}, 1 \mathrm{H}), 7.28(\mathrm{~m}, 2 \mathrm{H})$.

Synthesis of $N^{3}$-(2-chloro-6-fluorobenzyl)-1H-1,2,4-triazole-3,5-diamine, 16. A $0.913 \mathrm{~g}$ (5.72 mmol) of 2-chloro-6fluorobenzylamine 13 was dissolved in $12 \mathrm{~mL}$ of diethyl ether and added to a $20 \mathrm{~mL}$ microwave vial equipped with a magnetic stirring bar. Dimethyl cyanodithioiminocarbonate $14(1.0 \mathrm{~g}, 6.43 \mathrm{mmol})$ was then added and the vial was sealed. The contents were microwaved at $45^{\circ} \mathrm{C}$ for 5 minutes, then allowed to cool to room temperature, and the ether was removed in vacuo to yield the intermediate 15 as a white solid. Hydrazine hydrate $(0.275 \mathrm{~g}, 8.58 \mathrm{mmol})$ in 12 $\mathrm{mL}$ of ethanol was then injected into the vial, and the reaction was stirred to break up the intermediate solid. The dispersed reaction mixture was microwaved at $90^{\circ} \mathrm{C}$ for $10 \mathrm{~min}$ on high absorption. The mixture was allowed to cool to room temperature, and the ethanol was removed in vacuo to yield the crude product. The crude material was purified on silica $\left(10 \% \mathrm{MeOH}\right.$ in dichloromethane), to afford $1.27 \mathrm{~g}$ of pure $\mathrm{N}^{3}$-(2-chloro-6-fluorobenzyl)-1 $\mathrm{H}-1,2,4-$ triazole-3,5-diamine 16 as a white, amorphous powder (92\% yield). ${ }^{1} \mathrm{H}$ NMR $\left(400 \mathrm{MHz}, \mathrm{CDCl}_{3}\right) \delta 4.32(\mathrm{~s}, 2 \mathrm{H}), 7.20-$ $7.22(\mathrm{t}, 4 \mathrm{H}), 7.31-7.36(\mathrm{~m}, 2 \mathrm{H})$. UPLC retention time: $0.46 \mathrm{~min}$. MS calculated 241.05, found $242.30\left([\mathrm{M}+1]^{+}\right)$

Synthesis of $N^{3}-(2-($ naphthalen-1-yloxy)benzyl)-1H-1,2,4-triazole-3,5-diamine, 7. To a $20 \mathrm{~mL}$ microwave vial equipped with a magnetic stir bar was added $N^{3}$-(2-chloro-6-fluorobenzyl)-1H-1,2,4-triazole-3,5-diamine $\mathbf{1 6}$ (1.0 g, $4.14 \mathrm{mmol}$ $(0.86 \mathrm{~g}, 6.21 \mathrm{mmol}) \mathrm{K}_{2} \mathrm{CO}_{3}$, naphthalen-1-ol $(0.659 \mathrm{~g}, 4.55 \mathrm{mmol})$, and $12 \mathrm{~mL}$ of anhydrous dimethyl sulfoxide. The vial was then sealed and stirred to distribute contents evenly. The reaction was microwaved at $190^{\circ} \mathrm{C}$ for 6 min on high absorption, and the contents were poured into a beaker containing $100 \mathrm{~mL}$ crushed ice. The product was extracted with three $50 \mathrm{~mL}$ portions of diethyl ether, and the ether layer was washed with $25 \mathrm{~mL}$ of saturated $\mathrm{NaCl}$. The organic layer was dried over $\mathrm{Na}_{2} \mathrm{SO}_{4}$, filtered, and the filtrate was removed in vacuo to provide crude 7 . The crude material was purified on silica (10\% MeOH in dichloromethane), to afford pure $1.14 \mathrm{~g}$ of pure 7 in $56 \%$ yield as a white solid. ${ }^{1} \mathrm{H}$ NMR $\left(400 \mathrm{MHz}, \mathrm{CDCl}_{3}\right) \delta 4.66(\mathrm{~s}, 2 \mathrm{H}), 7.36-7.38(\mathrm{~d}, 2 \mathrm{H})$, 7.53-7.57 $(\mathrm{d}, 1 \mathrm{H}), 7.63-7.64(\mathrm{~m}, 1 \mathrm{H}), 7.68-7.70(\mathrm{~d}$, $1 \mathrm{H}), 7.84-7.85(\mathrm{~d}, 1 \mathrm{H}), 7.91-7.93(\mathrm{~d}, 2 \mathrm{H}), 8.15-8.16(\mathrm{~m}, 2 \mathrm{H}), 8.17-8.19(\mathrm{~m}, 1 \mathrm{H})$. UPLC retention time: $0.44 \mathrm{~min}$. MS calculated 331.14 , found $332.43\left([\mathrm{M}+1]^{+}\right)$

Synthesis of $N^{3}$-[6-(4-phenyl)phenyloxy]-1H-1,2,4-triazole-3,5-diamine 8 . To a $20 \mathrm{~mL}$ microwave vial equipped with a magnetic stir bar was added $N^{3}$-(2-chloro-6-fluorobenzyl)-1H-1,2,4-triazole-3,5-diamine (1.0 g, $4.14 \mathrm{mmol}$ (0.86 g, 6.21 mmol) $\mathrm{K}_{2} \mathrm{CO}_{3}$, 4-phenylphenol $(0.715 \mathrm{~g}, 4.55 \mathrm{mmol})$, and $12 \mathrm{~mL}$ of anhydrous dimethyl sulfoxide. The vial was then sealed and stirred to distribute contents evenly. The reaction was microwaved at $150^{\circ} \mathrm{C}$ for $6 \mathrm{~min}$ on high absorption, and the contents were poured into a beaker containing $100 \mathrm{~mL}$ crushed ice. The product was extracted with three $50 \mathrm{~mL}$ portions of diethyl ether, and the ether layer was washed with $25 \mathrm{~mL}$ of saturated $\mathrm{NaCl}$. The organic layer was dried over $\mathrm{Na}_{2} \mathrm{SO}_{4}$, filtered, and the filtrate was removed in vacuo to provide crude 8 . The crude material was purified on silica $(10 \% \mathrm{MeOH}$ in dichloromethane), to afford $1.14 \mathrm{~g}$ of pure 8 in $64 \%$ yield. ${ }^{1} \mathrm{H}$ NMR $\left(400 \mathrm{MHz}, \mathrm{CD}_{3} \mathrm{OD}\right) \delta 4.74(\mathrm{~s}, 2 \mathrm{H}), 6.85-6.87(\mathrm{~d}, 1 \mathrm{H})$, 7.26-7.28 (d, 2H), 7.38-7.42 (m, 1H), 7.47-7.51 (m, 2H), 7.62-7.64 (d, 2H), 7.68-7.71 (d, 2H), 7.77-7.81 (m, 1H), 7.85-7.88 $(\mathrm{m}, 1 \mathrm{H}), 8.15-8.17(\mathrm{~d}, 1 \mathrm{H})$. UPLC retention time: $0.43 \mathrm{~min}$. MS calculated 357.16, found $358.37\left([\mathrm{M}+1]^{+}\right)$Note: This reaction yielded a dechlorinated product due to stabilization of the aromatic ring via anchimeric assistance of the adjacent secondary nitrogen. The stabilization of the aromatic ring increases the ability of chlorine to act as a good leaving group, resulting in hydrogen abstraction and formation of the dechlorinated product.

\section{Peptide Synthesis ${ }^{3,4}$}

$\mathrm{N}^{\alpha}-$ Fmoc amino acids were purchased from the Advanced Chemtech (Louisville, KY) and AAPPTec (Louisville, KY). Fmoc-rink linker and aminomethylated polystyrene resin was purchased from the Novabiochem (Gibbstown, NJ). Reagent grade Piperidine was purchased from the Sigma Aldrich. All the other solvents were purchased from the VWR and Fisher and used without further purification. All of the cyclic and linear peptide analogues were synthesized by using standard $\mathrm{N}^{\alpha}$ Fmoc/tBu solid-phase peptide synthesis. Three channel PS3 automated peptide synthesizer from Protein Technologies, Inc. Tucson Arizona was used for peptide synthesis. The aminomethylated polystyrene resin $(0.25 \mathrm{mmol}, 0.36 \mathrm{mmol} / \mathrm{g})$ was placed in a $40 \mathrm{~mL}$ glass reaction vessel in the synthesizer and allowed to swell in $15 \mathrm{~mL}$ of DMF solution for $30 \mathrm{~min}$. Then the resin was washed with $15 \mathrm{~mL}$ of DMF ( 3 X 2min). The Fmoc linker was introduced to the swelled resin using mixture of 
Fmoc linker (1.0 mmol, 4 equiv), HBTU (1 mmol, 4 equiv) and NMM (2 mmol, 8 equiv) in DMF for 60 min. After coupling of the Fmoc linker to the resin, the resin was washed with $15 \mathrm{~mL}$ of DMF solution ( 5 X $2 \mathrm{~min}$ ). The Fmoc protecting group on the resin was removed with $15 \mathrm{~mL}$ of $20 \%$ piperidine in DMF ( $2 \times 15 \mathrm{~min})$ followed by washing with $15 \mathrm{~mL}$ of DMF (5 X 2 min). Then, a preactivated Fmoc-amino acid prepared by mixing a Fmoc-amino acid (4 equiv), HBTU (4 equiv), and NMM (8 equiv) in DMF was introduced into the reaction vessel, and the reaction was continued for 1 hour. The deprotection and coupling steps were repeated for each amino acid until desired sequence was obtained.

Once the fully protected peptide having desired sequence is obtained on resin $(0.25 \mathrm{mmol})$, orthogonal protective groups of the peptide (alloc protecting groups of Lys and allyl group of Glu) were selectively removed using mixture of $\mathrm{Pd}_{(}\left(\mathrm{PPh}_{3}\right)_{4}(30$ mg, 0.1 equiv), and DMBA (390 mg, 10 equiv) in $6 \mathrm{~mL}$ DMF:DCM (1:3) in the $40 \mathrm{~mL}$ reaction vessel under $\mathrm{N}_{2}$ atmosphere for $30 \mathrm{~min}$ for two times. Then the resin was washed with $15 \mathrm{~mL}$ of DMF ( 5 X $2 \mathrm{~min})$ and washed with $15 \mathrm{~mL}$ of $0.1 \mathrm{M} \mathrm{LiCl}$ in DMF solution ( 3 x $2 \mathrm{~min}$ ). It was again washed with $15 \mathrm{ml}$ of DMF ( $3 \mathrm{X} 2 \mathrm{~min}$ ). The resin was treated with PyBOP/HOBt/DIPEA (6, 6, and 12 equiv) in $6 \mathrm{~mL}$ of DCM: DMF: NMP (1:1:1) for $6 \mathrm{~h}$ twice for formation of the lactam bridge. Then resin was washed with DMF (3 X $2 \mathrm{~min}$ ) and the cyclic peptide was cleaved from the resin as very similar to the procedure described above for the linear peptide.

The purified peptides were characterized by HRMS and LC-MS. High resolution mass spectrometric data was taken in the positive ion mode using Brucker AUTOFLEX III MALDI-TOF instrument. LC-MS data was obtained in the positive ion mode using Waters LC-MS instrument [having Waters 2545 quaternary gradient module, Waters 2767 sample manager, Waters SFO fluidic organizer, Waters 3100 mass detector containing single quadrapole, and Waters PDA detector 2998] on Waters Xterra C18 column $(3.0 \times 100 \mathrm{~mm}, 5 \mu \mathrm{M})$. UPLC chromatograms obtained using a Waters Aquity UPLC (H class, PDA detector, sample manager FTN and quaternary solvent manager) fitted with a Waters BEH C18 column (2.1 x $100 \mathrm{~mm}$, $1.7 \mu \mathrm{M})$.

\section{Analytical Data for Compounds 4-11 (from references 52-54)}

$N^{3}$-(2-chloro-6-phenoxybenzyl)-4H-1,2,4-triazole- 3,5-diamine 4. ${ }^{1} \mathrm{H}-\mathrm{NMR}$ (400MHz, CD3OD/TMS) $\delta 4.21$ (s, 2H), 6.77$6.80(\mathrm{dd}, 1 \mathrm{H}), 6.99-7.01(\mathrm{~d}, 2 \mathrm{H}), 7.11-7.15(\mathrm{t}, 1 \mathrm{H}), 7.20-7.27(\mathrm{~m}, 2 \mathrm{H}), 7.33-7.38(\mathrm{t}, 2 \mathrm{H})$. UPLC retention time: $12.1 \mathrm{~min}$. MS calculated 315.09 , found $316.33\left([\mathrm{M}+1]^{+}\right)$

$N^{3}$-(2-chloro-6-(naphthalen-1-yloxy)benzyl)-1H-1,2,4-triazole-3,5-diamine, 5. ${ }^{1} \mathrm{H}$ NMR (400 MHz, DMSO) $\delta 4.49$ (s, 2H), 6.67-6.80 (dd, $1 \mathrm{H}), 6.99-7.01(\mathrm{~d}, 1 \mathrm{H}), 7.25(\mathrm{~d}, 2 \mathrm{H}), 7.54-7.59(\mathrm{~m}, 3 \mathrm{H}), 7.77-7.79(\mathrm{dd}, 1 \mathrm{H}), 7.99-8.01(\mathrm{dd}, 1 \mathrm{H}), 8.12-8.14(\mathrm{dd}$, 1H). UPLC retention time: $14.34 \mathrm{~min}$. MS calculated 365.10, found $366.21\left([\mathrm{M}+1]^{+}\right)$

$N^{3}$-(2-chloro-6-(naphthalen-2-yloxy)benzyl)-1H-1,2,4-triazole-3,5-diamine, 6. ${ }^{1} \mathrm{H} \mathrm{NMR}\left(400 \mathrm{MHz}, \mathrm{CD}_{3} \mathrm{OD}\right) \delta 2.14(\mathrm{~s}, 2 \mathrm{H})$, $6.72(\mathrm{dd}, 1 \mathrm{H}), 6.81-6.86(\mathrm{dd}, 1 \mathrm{H}), 7.07(\mathrm{~d}, 1 \mathrm{H}), 7.08(\mathrm{~s}, 1 \mathrm{H}), 7.17(\mathrm{~d}, 1 \mathrm{H}), 7.32(\mathrm{~m}, 3 \mathrm{H}), 7,51(\mathrm{dd}, 1 \mathrm{H}), 8.19(\mathrm{dd}, 1 \mathrm{H})$. UPLC retention time: $14.53 \mathrm{~min}$. MS calculated 365.82 , found $366.21\left([\mathrm{M}+1]^{+}\right)$

$N^{3}$-(2-(naphthalen-1-yloxy)benzyl)-1H-1,2,4-triazole-3,5-diamine, $7 .{ }^{1} \mathrm{H}$ NMR (400 MHz, $\left.\mathrm{CDCl}_{3}\right) \delta 4.66(\mathrm{~s}, 2 \mathrm{H}), 7.36-7.38$ (d, 2H), 7.53-7.57 (d, 1H), 7.63-7.64 (m, 1H), 7.68-7.70 (d, 1H), 7.84-7.85 (d, 1H), 7.91-7.93 (d, 2H), 8.15-8.16 (m, 2H), 8.17-8.19 (m, 1H). UPLC retention time: $0.44 \mathrm{~min}$. MS calculated 331.14, found $332.43\left([\mathrm{M}+1]^{+}\right)$.

$N^{5}$-(2-([1,1'-biphenyl]-4-yloxy)benzyl)-1H-1,2,4- triazole-3,5-diamine, 8. ${ }^{1} \mathrm{H}$ NMR $\left(400 \mathrm{MHz}, \mathrm{CD}_{3} \mathrm{OD}\right) \delta 4.74(\mathrm{~s}, 2 \mathrm{H}), 6.85-6.87(\mathrm{~d}, 1 \mathrm{H})$, 7.26-7.28 (d, 2H), 7.38-7.42 (m, 1H), 7.47-7.51 (m, 2H), 7.62- 7.64 (d, 2H), 7.68-7.71 (d, 2H), 7.77-7.81 (m, 1H), 7.85-7.88 (m, $1 \mathrm{H}), 8.15-8.17(\mathrm{~d}, 1 \mathrm{H})$. UPLC retention time: 0.43 min. MS calculated 357.16 , found $358.37\left([\mathrm{M}+1]^{+}\right)$.

H-ARAM-c $\left[K^{5} T A R K E^{10}\right] T G G-K A P R K Q L A K\left(\mathrm{~N}^{-C_{3}-}\left(\mathrm{CH}_{2}\right)_{6} \mathrm{CO}\right)-\mathrm{NH}_{2}$, 9. UPLC retention time: $0.273 \mathrm{~min}$; MS for $\mathrm{C}_{111} \mathrm{H}_{203} \mathrm{~N}_{37} \mathrm{O}_{29} \mathrm{~S}$ : Calc. 2550.53, found $845.6([\mathrm{M}+3 \mathrm{H}])^{+3}$.

H-ARTM- $C\left[K^{5} T A R K E^{10}\right] T G G-K A P R K Q L A K\left(N-\mathrm{CH}_{3}-\left(\mathrm{CH}_{2}\right)_{6} \mathrm{CO}\right)-\mathrm{NH}_{2}, 10$. UPLC retention time: 0.269 min; MS for $\mathrm{C}_{112} \mathrm{H}_{205} \mathrm{~N}_{37} \mathrm{O}_{30} \mathrm{~S}$ : Calc. 2580.54, found $855.5\left[(\mathrm{M}+3 \mathrm{H}]^{+3}\right.$.

$H$-ARAM-c[K ${ }^{5}$ TARKE $\left.E^{10}\right] T G G-K A P R K Q L A-O H, 11$. UPLC retention time: 5.16min; HRMS for $\mathrm{C}_{95} \mathrm{H}_{173} \mathrm{~N}_{37} \mathrm{O}_{24} \mathrm{~S}$ : Calc. 2250.67, found $2251.357(\mathrm{M}+1 \mathrm{H})^{+}$

\section{Enzyme Assay}

Compounds were evaluated for the ability to inhibit recombinant LSD1/CoREST using a commercially available assay kit (\#700120, Cayman Chemical, Ann Arbor, MI). The substrate and all compounds were incubated in assay buffer from $30 \mathrm{~min}$ up to $4 \mathrm{~h}$ at $37^{\circ} \mathrm{C}$ as described in the commercial protocol. The volume of each reaction well 
was $50 \mu \mathrm{l}$, containing $5 \mu \mathrm{l}$ of a $200 \mu \mathrm{M}$ solution of substrate peptide and $20 \mu \mathrm{l}$ of a $15 \mathrm{ng} / \mu \mathrm{l}$ enzyme solution. All compounds were diluted in $1 \%$ DMSO with assay buffer to a final volume of $50 \mu \mathrm{M}$. Fluorescence was measured at the recommended wavelengths of $\mathrm{kex}=530 \mathrm{~nm}$, kem $=590 \mathrm{~nm} . \mathrm{IC}_{50}$ determinations were performed using serial dilutions at $250,125,62.5,31.25,6.25,3.125,1.563,0.781$ and $0.390 \mu \mathrm{M}$. All blanks contained 1\% DMSO to determine any solvent effects.

\section{Cell Culture}

K562 (human myelogenous leukemia) cells were purchased from ATCC. Cells were cultured in Iscove's Modified Dulbecco's Medium containing $10 \%$ (v/v) fetal bovine serum and 5\% penicillin and streptomycin, as previously described. ${ }^{54}$ All cultures were grown at $37^{\circ} \mathrm{C}$ in a humidified environment containing $5 \% \mathrm{CO}_{2}$.

CD34 ${ }^{+}$cells were expanded in H3000 media supplemented with CC100 (Stem Cell Technologies) for 4 days at a density of $10^{5}$ cells $/ \mathrm{mL}$ prior to use for compound evaluation. Cells were treated for 24,48 or 72 hours with an appropriate concentration of each analogue.

\section{Cell Viability Assay}

All cell lines were purchased from ATCC (Manassas, VA). For the (3-(4,5-dimethylthiazol-2-yl)-5-(3-carboxymethoxy-phenyl)-2-(4-sulfo- phenyl)-2H-tetrazolium) (MTS) reduction assay, 2000 cells per well were seeded in $50 \mu \mathrm{L}$ of complete medium per well of a 96 -well plate and the cells were allowed to attach overnight at $37^{\circ} \mathrm{C}$ in a $5 \% \mathrm{CO}_{2}$ atmosphere. The medium was aspirated and cells were treated with $100 \mathrm{~mL}$ of fresh medium containing appropriate concentrations of each inhibitor to be tested. The cells were incubated for $72 \mathrm{~h}$ at $37^{\circ} \mathrm{C}$ in $5 \% \mathrm{CO}_{2}$, after which $20 \mathrm{~mL}$ of the MTS reagent solution (Promega CellTiter 96 Aqueous One Solution Cell Proliferation Assay) was added to the medium. The cells were incubated for another $2 \mathrm{~h}$ at $37^{\circ} \mathrm{C}$, and absorbance was measured at 490 $\mathrm{nm}$ on a SpectraMax M5 instrument (Molecular Devices) equipped with SOFTmax PRO 4.0 software to determine cell viability. A reference wavelength of $690 \mathrm{~nm}$ was used to subtract the background. Percent cell death was calculated by the following equation: \% Cell Death $=($ Abs Control - Abs sample $) /$ Abs Control X100. A dose response curve was constructed for each inhibitor, and each data point was the average of 3 determinations obtained during a single experiment \pm S.E.M. $\mathrm{IC}_{50}$ values were calculated using the GraphPad Prism 5 software package (Graph-Pad, San Diego, California).

\section{RT-qPCR}

Media was rinsed with PBS and cells were lysed using TriZol Reagent (Invitrogen, Cat\# 15596026). mRNA was isolated according to manufacturer's protocols and purity confirmed using a Nanodrop-1000 spectrophotometer (Thermo Fisher). Quantitative reverse-transcription real time polymerase chain (qRT-PCR) reaction was run using a High-Capacity cDNA Reverse Transcription Kit (Applied Biosystems, Cat\# 4368814) followed by TaqMan ${ }^{\circledR}$ Fast Advanced Master Mix (Applied Biosystems, Cat\# 4444557) with TaqMan ${ }^{\circledR}$ Gene Expression Assay Primers (Applied biosystems, listed below) using a StepOne Plus instrument (Thermo Fisher). TNF- $\alpha$, IL-6 and the internal control GAPDH were then quantitated for each sample in triplicate. Results are reported as fold change $\left(2^{-\wedge} \mathrm{CT}\right)$.

\section{Primary rat cardiomyocyte isolation}

Primary male Sprague-Dawley rat cardiomyocytes were isolated via a hanging heart preparation using enzymatic digestion, as previously described.$^{52}$ In brief, rats were euthanized with $5 \%$ isoflurane vaporized in $100 \% \mathrm{O}_{2}$. The heart was retrogradely perfused with collagenase. The cardiomyocytes were plated on 6-well culture trays that were coated with laminin at an initial plating density of $1.5 \times 10^{5}$ cells/well. After overnight incubation, the cardiomyocytes were rinsed and maintained in serumfree medium.

\section{Co-immunoprecipitation}

Primary rat cardiomyocytes were isolated as described earlier and treated with varying concentrations of test compounds. Cells were lysed and scraped with IP Lysis Buffer $(20 \mathrm{mM}$ Tris-Cl, $150 \mathrm{mM} \mathrm{NaCl}, 1 \mathrm{mM}$ EDTA, $1 \mathrm{mM}$ EGTA, $1 \mathrm{mM} \beta$-glycerol, $2.5 \mathrm{mM}$ Na pyrophosphate). Dynabeads (Life Biosciences) were added (1:10 beads:lysate $\mathrm{v} / \mathrm{v}$ ) and incubated at $4{ }^{\circ} \mathrm{C}$ for 1 -hour to pre-clear. Mixture was centrifuged (5000rpm) and the supernatant was saved. An antibody $(2-5 \mu \mathrm{g})$ for the protein of interest was added and rocked overnight in cold room. Dynabeads $(20 \mu \mathrm{L})$ were added and incubated at room temp for 1-hour. Centrifuge mixture for 1-minute at 5000rpm. The supernatant was decanted and the pellet washed 3X with IP Lysis Buffer with $0.1 \%$ Triton X-100. Samples were then analyzed by SDS-PAGE and immunoblotted. 


\section{Preliminary Toxicology}

Toxicology screen of Compound 4 in CD1 mice: We performed a pilot toxicology study in four CD1 mice to determine whether 3,5-diamino-1,2,4-triazoles such as $\mathbf{4}$ caused any acute organ toxicities as determined by blood factor analysis and histology. This study was performed in collaboration with the MUSC Veterinary Services. In short, a $3 \mathrm{mg} / \mathrm{kg}$, intraperitoneal injection of compound $\mathbf{4}$ was administered daily for 1-week. After the drug course, mice were evaluated by the MUSC veterinarian. In vivo treatment with $\mathbf{4}$ revealed only minor anomalies: slight elevation of the BUN/creatine ratio and minor thrombocytopenia. Histology revealed minor ectactic cortical tubules with attenuated epithelium and minor vacuolization of cardiomyocytes. No hepatic inflammation or necrosis, lung pathology or splenic changes were seen. A complete blood panel, liver enzymes, and kidney functional labs were obtained, followed by histological evaluation of various organs (i.e. heart, lung, liver, spleen, and kidney). A comprehensive report on histological damage was obtained by a veterinary pathologist. In addition, a consultation with an MUSC Hematology Resident and Nephrologist were also performed. Upon gross examination, all four mice showed no abnormalities or contraindications from drug treatments. The blood panel and liver enzymes had no outstanding findings and were within normal range. However, blood urea nitrogen (BUN) was elevated, creatinine was low, and blood glucose was elevated (Table S1). Thus, the BUN:creatinine ratio was higher than reported normal values. In addition, the CBC showed minor thrombocytopenia.

Table S1. Laboratory values for CD-1 mice treated for 1 week with compound 4.

\begin{tabular}{|c|c|c|c|}
\hline \multicolumn{4}{|c|}{ Blood Diagnostic Tests } \\
\hline & Normal Range \# & \multicolumn{2}{|c|}{ Compound $9 ¥$} \\
\hline ALT & $45.08 \pm 2 \mathrm{u} / \mathrm{L}$ & \multicolumn{2}{|c|}{$42.75 \pm 5.0$} \\
\hline AST & $80.55 \pm 8.3 u / L$ & \multicolumn{2}{|l|}{$165.25 \pm 17.8$} \\
\hline ALP & 14-118 u/L & \multicolumn{2}{|l|}{$66.67 \pm 21.5$} \\
\hline CREATININE & $11.3 \pm 0.1 \mathrm{mg} / \mathrm{dL}$ & \multicolumn{2}{|l|}{$0.15 \pm 0.03$} \\
\hline BUN & $14.68 \pm 0.5 \mathrm{mg} / \mathrm{dL}$ & \multirow{2}{*}{\multicolumn{2}{|c|}{$\begin{array}{c}22 \pm 1.5 \\
263.5 \pm 19.5\end{array}$}} \\
\hline GLU & $164.89 \pm 3.5 \mathrm{mg} / \mathrm{dL}$ & & \\
\hline \multicolumn{4}{|l|}{ Leukocytes } \\
\hline WBC & $8.79 \pm 0.3(\mathrm{k} / \mu \mathrm{L})$ & \multicolumn{2}{|l|}{$5.3 \pm 0.9$} \\
\hline NE & $1.5 \pm 0.1(\mathrm{k} / \mu \mathrm{L})$ & \multicolumn{2}{|l|}{$1.1 \pm 0.1$} \\
\hline LY & $6.59 \pm 0.3(\mathrm{k} / \mu \mathrm{L})$ & \multicolumn{2}{|l|}{$4.0 \pm 0.8$} \\
\hline MO & $0.49 \pm 0.03(\mathrm{k} / \mu \mathrm{L})$ & $0.13 \pm 0.03$ & $L$ \\
\hline EO & $0.17 \pm 0.02(\mathrm{k} / \mu \mathrm{L})$ & \multicolumn{2}{|l|}{$0.07 \pm 0.02$} \\
\hline BA & $0.04 \pm 0.01(\mathrm{k} / \mu \mathrm{L})$ & \multicolumn{2}{|l|}{$0.01 \pm 0.01$} \\
\hline NE\% & $6.6-38.9 \%$ & \multicolumn{2}{|l|}{$20.5 \pm 2.1$} \\
\hline LY\% & $55.8-91.6 \%$ & \multicolumn{2}{|l|}{$75.3 \pm 2.6$} \\
\hline MO\% & $0-7.5 \%$ & \multicolumn{2}{|l|}{$2.5 \pm 0.6$} \\
\hline EO\% & $0-3.9 \%$ & \multicolumn{2}{|l|}{$1.4 \pm 0.5$} \\
\hline BA\% & $0-2 \%$ & \multicolumn{2}{|l|}{$0.31 \pm 0.2$} \\
\hline \multicolumn{4}{|l|}{ Erythrocytes } \\
\hline RBC & $8.93 \pm 0.2(\mathrm{M} / \mu \mathrm{L})$ & \multicolumn{2}{|l|}{$10.3 \pm 0.9$} \\
\hline $\mathrm{Hb}$ & $14.67 \pm 0.3(\mathrm{~g} / \mathrm{dL})$ & \multicolumn{2}{|l|}{$15.6 \pm 1.4$} \\
\hline HCT & $49.97 \pm 1.1(\%)$ & \multicolumn{2}{|l|}{$54.4 \pm 5.3$} \\
\hline MCV & $56.1 \pm 0.6(f L)$ & \multicolumn{2}{|l|}{$52.8 \pm 1.8$} \\
\hline $\mathrm{MCH}$ & $16.45 \pm 0.6(\mathrm{pg})$ & \multicolumn{2}{|l|}{$15.2 \pm 0.3$} \\
\hline MCHC & $29.5 \pm 0.4(\mathrm{~g} / \mathrm{dL})$ & \multicolumn{2}{|l|}{$28.9 \pm 1.0$} \\
\hline RDW & $16.79 \pm 0.1(\%)$ & \multicolumn{2}{|l|}{$16.4 \pm 0.4$} \\
\hline \multicolumn{4}{|l|}{ Thrombocytes } \\
\hline PLT & $1529 \pm 53(\mathrm{~K} / \mu \mathrm{L})$ & $836.5 \pm 324$ & $L$ \\
\hline MPV & $5.1 \pm 0.06(\%)$ & \multicolumn{2}{|l|}{$5.1 \pm 0.1$} \\
\hline
\end{tabular}

\# Normal clinical laboratory values as reported by

Charles River Laboratories, CD1 mouse supplier

$¥ 3 \mathrm{mg} / \mathrm{kg}$, i.p. $Q D \times 7$ days; $n=4$ CD1 mice 
Histological evaluation by hemotoxylin and eosin staining of various organs revealed very minimal to minor pathological changes. Of note, the kidney showed minor ectatic cortical tubules with attenuated epithelium (Figure S1A). In addition, the heart showed minor vacuolation of cardiomyocytes without any interstitial immune infiltration (Figure S1B). There was also negligible multifocal hepatic inflammation and necrosis (Figure S1C). Finally, the spleen showed no outstanding lesions (not shown).

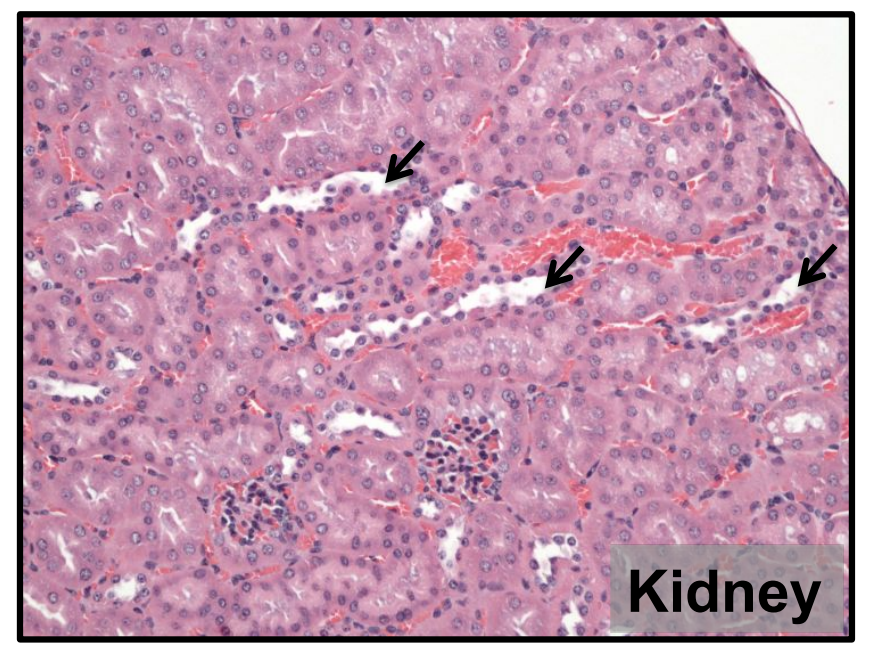

Figure S1A. Kidney histology of compound 4 treated CD1 male mice (3mg/kg, i.p., QD 7 days). Hemotoxylin and eosin staining of cortical kidney. Mild multifocal ectatic tubules with attenuated epithelium (Arrow). Limited tubular hyperplasia and regeneration. (Reported in 2 of 4 animals).

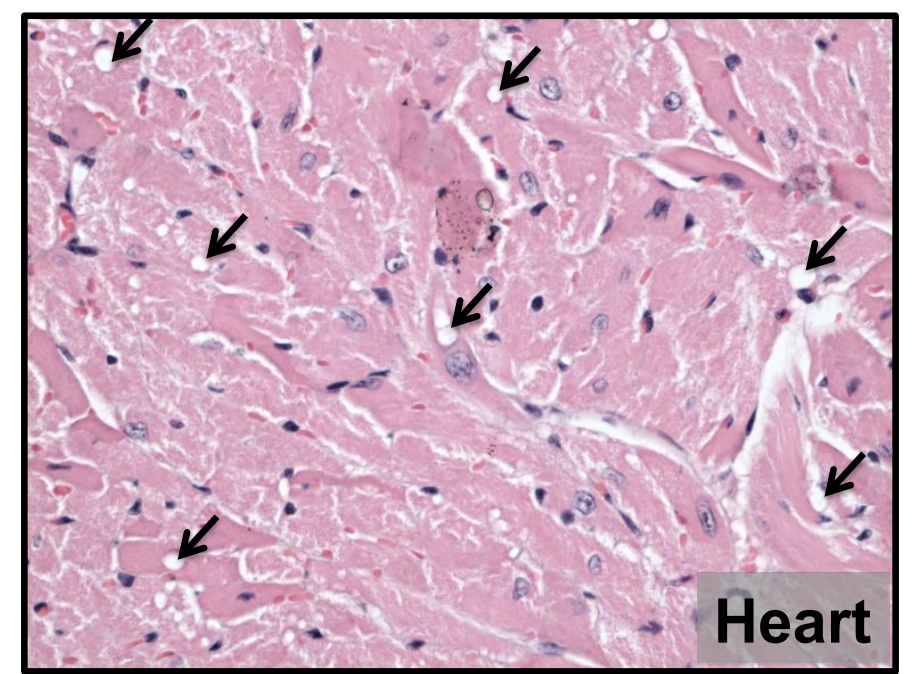

Figure S1B. Heart histology of compound 4 treated male CD1 mice (3mg/kg, i.p., QD 7 days). Hemotoxylin and eosin staining of left ventricular free wall. Mild diffuse cardiomyocyte intrasarcoplasmic vacuolation without interstitial infiltrate. (Reported in 2 of 4 animals). 


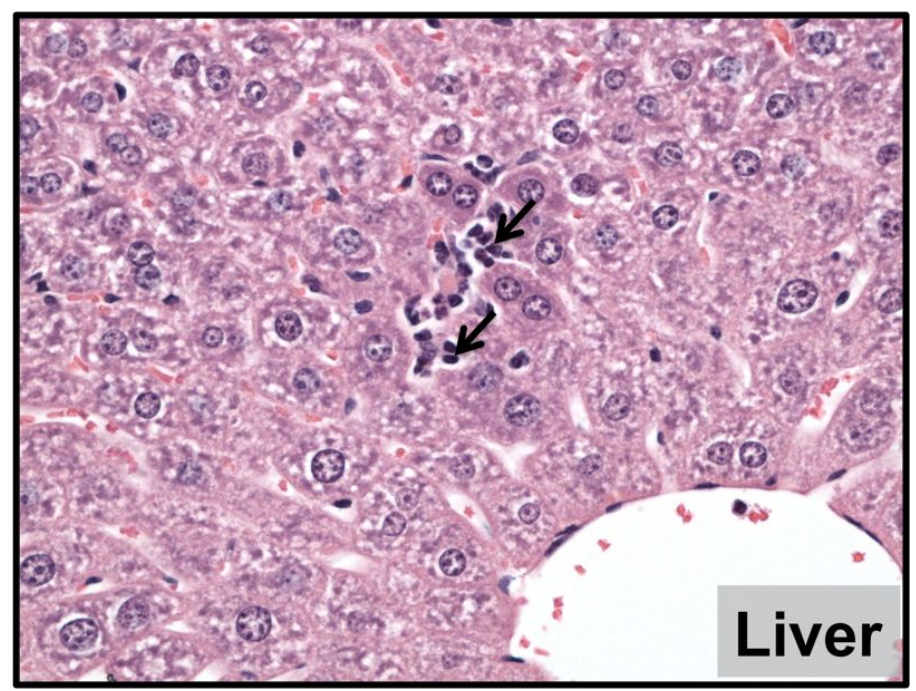

Figure S1C. Liver histology of compound 4 treated male CD1 mice (3mg/kg, i.p., QD 7 days). Hemotoxylin and eosin staining of left lobe. Mild multifocal hepatic inflammation and necrosis can be found, as indicated by the arrows. (Reported in 3 of 4 animals).

\section{References}

52. Kutz, C. J.; Holshouser, S. L.; Marrow, E. A.; Woster, P. M.: 3,5-Diamino-1,2,4-triazoles as a novel scaffold for potent, reversible LSD1 (KDM1A) inhibitors. MedChemComm 2014, 5 (12), 1863-1870. PM CID: 4286191.

53. Holshouser, S.; Dunworth, M.; Murray-Stewart, T.; Peterson, Y. K.; Burger, P.; Kirkpatrick, J.; Chen, H. H.;

Casero, R. A., Jr.; Woster, P. M.: Dual inhibitors of LSD1 and spermine oxidase. MedChemComm 2019, 10 (5), $778-790$. PM CID: 6533887.

54. Kumarasinghe, I. R.; Woster, P. M.: Cyclic peptide inhibitors of lysine-specific demethylase 1 with improved potency identified by alanine scanning mutagenesis. Eur. J. Med. Chem. 2018, 148, 210-220. PM CID: PMC5837957. 